\title{
Study of Manufacture Company Strategy in Implementing ISO 9001:2015 \& ISO 140001
}

\author{
Zikri Habibie Muhammad Akrim ${ }^{1 *}$, Filson Maratur Sidjabat ${ }^{2}$ \\ ${ }^{1}$ Environmental Engineering, President University, Bekasi, Indonesia \\ "Email: zikrihabibie@yahoo.com \\ ${ }^{2}$ Environmental Engineering, President University, Bekasi Indonesia
}

\begin{abstract}
(C) 2019 - UEJ Program Studi Pendidikan Kependudukan dan Lingkungan Hidup Universitas Negeri Makassar. Ini adalah artikel dengan akses terbuka dibawah Licensi CC BY-NC-4.0 (https://creativecommons.org/licenses/by-nc/4.0/)
\end{abstract}

\begin{abstract}
In early 1980's environmental issues were increasing, several policies were made in countries as a concern to environment, even the government has the policy about environment. One of the standards used in company related to environment is ISO 14001.Beside environmental management system companies need to get an international confession stating that their products and systems are appropriate. The international standard related to the quality management that can be used is ISO 9001:2015.In this study author try to comparing manufacturing company such asPT. Apac Inti Corpora, Omron Manufacturing and LG Electronicstrategy in implementing the ISO 9001:2015 and ISO 14001:2015 certification.
\end{abstract}

Keywords:Enviromental, manufacture, strategy, implementing, company

\section{INTRODUCTION}

Since 1980s, environmental issues were increasing, several policies were made in countries as a concern to environment, even the government has the policy about environment. One of the standards used in company related to environment is ISO 14001.International Standard Organization (ISO) 14001 is a standard used to help a company realize industrial management of the environment. ISO 14001 for the company has become a reference for carrying out attention to the environment in every aspect of the operations and procedures implemented by a company.[1]

Manufacturing company that has received ISO 14001: 2015 certification including PT. Apac Into Corpora, PT. Omron Manufacturing Indonesia and PT LG Indonesia. PT. APAC INTI CORPORA (AIC) is a textile company located in Bawen, Semarang, Central Java. PT.AIC has three products, namely yarn (yarn), fabric (greige), and denim. PT.AIC itself has 3 certifications, namely ISO 9001 certification on quality, ISO 50001 on energy, and ISO 14001 on environmental management. PT.AIC company has received ISO 14001 certification in 2002 from SI Global about environmental management systems. PT. Omron Manufacturing Indonesia is a manufacturing company engaged in the Automation System, Motion / Drive, Robot \& Safety Components. On February 25, 2019 PT Omron Manufacturing Indonesia renewed ISO 14001: 2015 certification. This shows their commitment to the Environmental Management System.[2]

PT. LG Electronics Indonesia is a manufacturing company engaged in Home Appliances, Mobile Communication, TV. In 2007 PT LG Electronic Indonesia managed to get ISO 14001 certification from TUV Rheinland and obtained ISO 9001 in 2008.[3]

\section{METHODS}

In ISO 9001:2015, the adoption of a quality management system $\mathrm{s}$ a strategic decision for an organization that can help to improve its overall performance and provide a sound basis for sustainable development initiatives. The potential benefits to an organization of implementing a quality management system based on this International Standard are: 
UNM Environmental Journals, Vol. 2 No. 2 April hal. $28-33$

a) The ability to consistently provide products and services that meet customer and applicable statutory and regulatory requirement.

b) Facilitating opportunities to enhance customer satisfaction

c) Addressing risk and opportunities associated with its context and objectives

d) The ability to demonstrate conformity to specified quality management system requirement.[4]

An environmental management system based on ISO 14001 was developed to evaluate and develop environmental culture in a company. Besides that, implementing an environmental management system will give positive value to the company's performance. ISO 14001 develops a model for implementing an environmental management system within a company that can be seen from the organizational structure, planning activities, practices, procedures, processes, resources to prepare, implement, review, and maintain corporate environmental policies.[5]

Methods have been used to compiled this journal is literature review, author comparing 3 Manufacturing company method and strategy inimplementation of ISO 14001:2015 and ISO 9001: 2015.

\section{RESULT AND DISCUSSION 1. PT APAC INTO Corpora}

\section{Quality Assurance}

The core strength of AIC is the consistent good quality of its products, which matches international standards. Diligent attention to every detail in every stage of production process is a well- established hallmark of AIC. The company's constant push for quality starts from careful selection of raw material, on- line and off- line process control throughout the process till finished product stage.

In order to achieve high level of quality and to maintain the reputation as a quality product supplier, a team of highly qualified, dedicated and experienced professionals in the company's quality control section perform round the clock control using latest testing equipment for both on- line and off- line controls. In addition to this, advanced information- technology is used at all stages. All cotton bales are thoroughly cleaned by hand sorters with full perfection to extract contamination, and further baled, wrapped by cotton cloth cover and stored. $100 \%$ of the bales are checked by Uster HVI Tester. The testing laboratories are equipped with the latest testing equipment such as Uster Tester 3, UsterTensorapid, UsterClassimat and a number of instruments for testing yarns and fabrics.

All ring spun yarns are air- spliced and electronically cleared by Uster cleaners. Open- End yarns are controlled by Corolab clearing system. Greige and Denim fabrics are fully inspected as per international system. Our yarns, greige fabric and Denim fabric are Eco- friendly and are free from harmful substances as certified by Oeko- Tex, Testex, and Zurich.

Production facilities are air- conditioned. The temperature and humidity are controlled by Amelio (LTG) air- conditioning systems, which result in high operational efficiency and consistent quality. Quality is the top priority of the company. Hence, rigorous quality assurance steps are taken to maintain the company's leadership in quality. Quality is not job by accident but achieved by meticulous planning and execution.

\section{Environmentally Friendly}

Operating 24 hours a day, our waste water treatment plant processes the entire liquid waste released by production process. Consistent operation of physical, chemical and biological system enables us to discharge cleaner \& harmless water to the river at $30-40 \%$ better than the standard level mandated by the government. Solid Waste Dryer and Incinerator are used to process our solid waste. This unit also operates 24 hours a day, ensuring the quality and continuity of solid waste treatment. The outcome of this process is a very stable material, with close to zero water levels. Strict surveillance are taken to meet quality standards set by the government. 
Entire process and safe water resulted by waste water treatment discharged to public waterway, are continuously monitored. The main parameters tested are: $\mathrm{pH}$, TSS, TDS, COD, BOD5, Ammonia, Phenol, Oil, and heavy metal essence.

AIC are consistently executing the principles of "Cleaner Production". Their Waste Water Treatment Plan compiled $3 \mathrm{R}$

a) Reduce: Reducing the use WWTs water supply without reducing the quality of end- result. Thus, trying to change water supply with more environmentally friendly ones and controlling the use of water compactly.

b) Reuse: Reusing processed water form Waste Water Treatment and other process as water supply for the industry that doesn't need high standard.

c) Recycle: In AIC try to recycle and water discharged to Public steam and turn it into ready- to- use water supply for the industry. As a result, we will have zero discharge. [7]

\section{PT. Omron Global Manufacturing}

\section{Identify Sustainability Issues and Setting Goals}

For the 1st Step Omron Manufacturing try to identify Issues, OMRON try to analyze global social issues and Sustainable Development Goals Trends. Continuing identify a broad range of environmental, social and economic issues. 2nd Step Set Priorities and Goals, Omron Manufacturing implemented to worked with the relevant departments to analyze the materiality of issues through stakeholder also OMRON. Final Step their try to discussed at the executive council with the CEO acting as a meeting chair continuing approved by the board of director.

\section{Environmental Education and Awareness Enhancement}

OMRON provided environmental education programs targeting all employees as well as rankspecific programs with the aim of promoting environmental preservation efforts across the Group. To raise public awareness of environmental preservation, OMRON participated in an environmental education program for elementary school students organized by the Kyoto Chamber of Commerce and Industry. OMRON employees gave lectures on environment-related subjects at one school.

\section{Environmental Investment}

OMRON keeps track of investments in equipment the company makes for reducing the environmental impact of its business activities, as well as the economic benefits resulting from reduced environmental impact throughout the world.

Tabel 1 Capital Investment for Environmental Impact Reduction (Japan and Overseas)

\begin{tabular}{|l|r|r|r|r|r|}
\hline & \multicolumn{5}{|c|}{ Units: Millions of yen } \\
\hline $\begin{array}{l}\text { Investment in equipment for environmental } \\
\text { impact reduction }\end{array}$ & FY2013 & FY2014 & FY2015 & FY2016 & FY2017 \\
\hline $\begin{array}{l}\text { Economic benefits in a year resulting from } \\
\text { environmental impact reduction }\end{array}$ & 314 & 555 & 447 & 164 & 470 \\
\hline
\end{tabular}




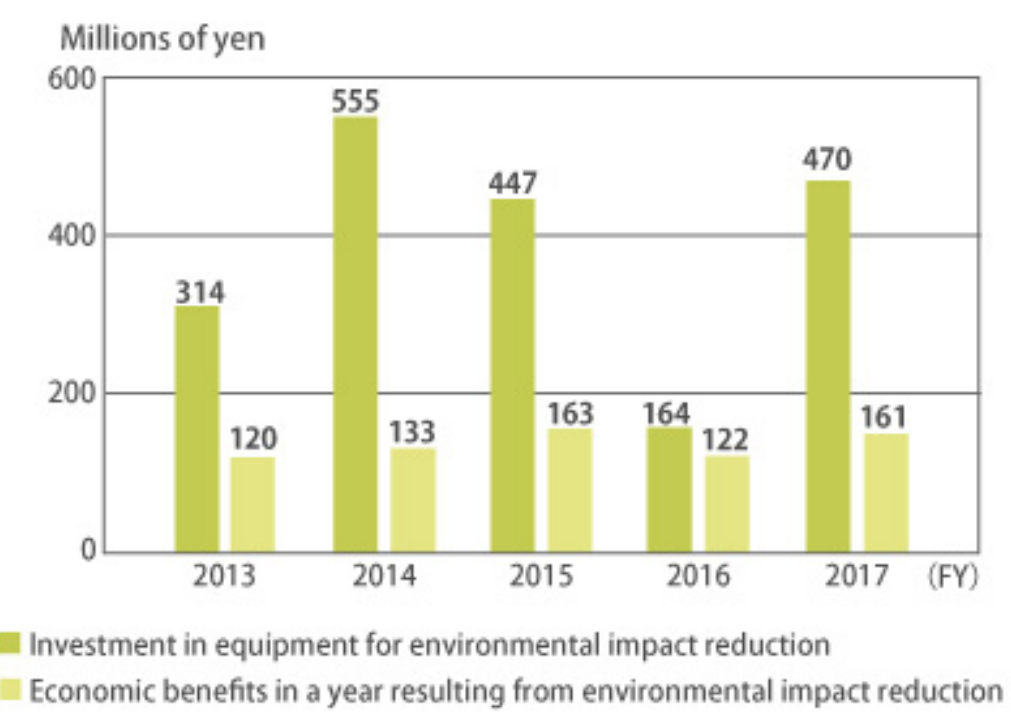

\section{Graph 1.1 Capital Investment for Environmental Impact Reduction (Japan and Overseas)}

From the table and graph above in fiscal year 2017 by investing $¥ 470$ Million globally, Omron Manufacturing get $¥ 161$ Million as an economic benefit in a year resulting from environmental impact reduction. Average of economic benefits in five years are $¥ 131$ million and for the highest benefits income has shown in 2015.[2]

\section{Value Generation $2.0(2020)$}

During the past decade, OMRON has enjoyed stable business performance. But to put the company back on the high-growth path, it was necessary to implement structural reforms that improve both sales and profitability. In the VG2020 strategy, OMRON focusing on the industrial automation business in emerging markets centered on Asia. This approach is aimed at restoring OMRON's growing capability by going back to our roots. By contrast, in developed markets and on a global scale, we will accelerate the creation of new businesses.

To help bring upcoming plans to fruition, OMRON are promoting profit structure reform and the global human resources strategy. Particularly with the global human resources strategy, we are committed to appointing local employees to management positions at overseas operating sites, which is essential to ensuring the globalization of business operations. In overseas operating sites, management positions filled by local employees accounted for about $30 \%$ of such positions in fiscal 2011. By fiscal 2014, this percentage had increased to $42 \%$, and our goal is to increase it to $66 \%$ by 2020.

\section{PT. LG Electronic Indonesia Sustainable Commitment}

LG Electronics Indonesia aims for sustainability management in consideration of the present and future economy, society, and environment based on its management philosophy, "People-Oriented Management" and "Customer-Value Creation". Joint efforts with customers, environmental organizations, suppliers, communities, employees, and other stakeholders must be made to change the future. Through these partnerships, we can partake in the corporate social responsibility activities of the international society, such as governments and NGOs of each country. In the end, LG Electronics 


\section{Zikri Habibie, Study of Manufacture Company Strategy}

plans to contribute to sustainable growth by implementing three commitments and nine Goals on a mid- to long-term basis.

\section{Promote Intelligent Lifestyle}

Become a company that delivers "intelligent lifestyle" by expanding green business and launching several innovative products for healthy lifestyle while also offering more convenient and accessible connection between people and things. There are 3 Goals in promoting intelligent lifestyle:

1. Establish Intelligent Living Environment

Improve the life of customers by providing more easy-to-use products applied with AI and future technology.

2. Pursue Healthy Life for Customers

Help customers live a healthy life by launching cutting-edge products with social and environmental changes in mind.

3. Expand Green Business

Contribute to creating a sustainable society through continuous development of environmentally friendly businesses such as renewable energy and EVs.

\section{Realize Zero Carbon and Circular Economy}

Become a company that contributes to circular economy by striving to pursue zero carbon through the reduction of $\mathrm{CO} 2$ emissions, development of energy efficient products, removal of harmful environmental effects of products, and managementof wastes from all production stages and e-waste after the use of products. There are 3 Goals in Implementing Zero Carbon and Circular Economy:

1. Pursue Zero Carbon Pursue "Zero Carbon" by reducing greenhousegas emissions and developing energy-efficient products.

2. Reduce the Environmental Impacts of Products Reduce the environmental effects of productsthroughout the processes of raw materialmining, production, use, and disposal.

3. Promote Circular Economy Contribute to creating a circular economyby managing the waste and e-Waste aftertheir production and use.

\section{Create Better Society}

Become a company that plays a leading role in creating a better society by providing support for creating a sustainable business ecosystem throughout the supply chain, creating a safer work place and promoting work and life balance while also improving work efficiency, encouraging employees to participate in volunteer activities, and contributing more to society through the utilization of products and services. There are 3 Goals to Create Better Society:

1. Establish Sustainable Supply Chain, Create a sustainable business ecosystemthrough CSR management of the supplychain including raw material sourcing.

2. Establish decent and Safe work Place, Improve the level of employee satisfactionby creating a work environment with workand life balance.

Expand Contribution to the Local Community Contribute to expanding more value for thelocal community as a global corporate citizenwith products and services.[6]

\section{CONCLUSION}

In conclusion in this 3-manufacturing company there are different method was compiled to implement the ISO 14001 and ISO 9001. For AIC itself there was compiled 2 main strategy including quality assurance and environmentally friendly. For OMRON Manufacturing was implementing long term strategy VG.2.0 and for LG Electronic was 
UNM Environmental Journals, Vol. 2 No. 2 April hal. $28-33$

implemented mid to long term strategy including 3 commitments and separated into 9 goals sustainability commitments.

\section{ACKNOWLEDGEMENT}

This study was kindly supported by Mr. FilsonMaraturSidjabat to fulfill Environmental Quality Management System Final Stest project

\section{REFERENCES}

Y. Mauliddina and A. Susanty, "Evaluasi Faktor Sukses Implementasi Iso 14001 Dengan Metode Analytical Hierarchy Process (AHP) Di PT. Apac Inti Corpora Semarang," Ind. Eng. Online J., vol. 4, no. 4, 2015.

Omron Manufacturing, "Omron Integrated Report 2017," 2017.

S. Report, "Lg 2014-2015,” 2015.

I. O. for Standarization, "Standar Internasional ISO 9001:2015 Sistem Manajemen Mutu Persyaratan," pp. 0-60, 2015.

International Organization for Standardization, "Introduction to ISO 14001:2015," Introd. to ISO 140012015, pp. 1-13, 2015.

LG Electronics, "LG Electronics Sustainability Report," 2017-2018 LG Electron. Sustain. Rep., 2018.

Hessami, H.Z, Golsefid-Alavi, M, Shekaf, S.M, Mavi, R.K. 2012. "Evaluation of Success Factor of ISO 14001-Based EMS Implementation and Ranking the Cement Industry using the TOPSIS Method". Journal of Applied Environmental and Biological Sciences Vol 2, pp 523-530

Wulandari, R.S, Soemirat, J, Rahardyan, B. 2012. "Analysis of Success Factors of ISO 14001 Implementation : A Case Study in a Cement Company in Indonesia". Southeast Asian Network of Ergonomics Societies Conference (SEANES).

Sharifabadi, A.M, Sadrabadi, A.N, Jahromi, M.N. "Evaluation of the Effective Factors on Organizational Success in Implementation of Environmental Management System (EMS) : a case of Iranian Tile and Ceramic Industry".International JournalEconomic Management Social Science Vol 3, no 12, pp 816-821. 